\title{
Clinical Pharmacokinetics of a Lipid-Based Formulation of Risperidone, VAL401: Analysis of a Single Dose in an Open-Label Trial of Late-Stage Cancer Patients
}

\author{
Suzanne J. Dilly ${ }^{1}$ ] $\cdot$ George S. Morris ${ }^{1} \cdot$ Paul C. Taylor $^{2} \cdot$ Frederic Parmentier $^{3} \cdot$ Coralie Williams $^{3}$. \\ Mohammad Afshar ${ }^{3}$
}

Published online: 9 January 2019

(c) The Author(s) 2019

\begin{abstract}
Background and Objectives A clinical trial was conducted to measure and analyse the pharmacokinetic parameters of a lipid formulation of risperidone, VAL401. The VAL401 formulation is designed to repurpose risperidone from an antipsychotic to an adenocarcinoma treatment, with the lipid formulation altering the cellular uptake of risperidone, thus enabling anticancer biology to be exhibited in preclinical testing.

Methods This first human trial of VAL401 measured the concentrations of risperidone and its primary metabolite, 9-hydroxyrisperidone, in the blood of patients after treatment with a single 2-mg dose of VAL401.

Results The trial provided information on differences in the pharmacokinetic profile of risperidone in VAL401 that may be caused by the formulation and/or the nature of the cancer patient population. VAL401 provided the following key pharmacokinetic parameters for the risperidone plasma concentration after a single 2-mg dose of VAL401, with results normalised to a dosage of $1 \mathrm{mg}$ for comparison with literature values: $T_{\max }, 2 \mathrm{~h} ; C_{\max }, 8 \mathrm{ng} / \mathrm{ml}$; half-life, $3.5 \mathrm{~h}$; area under the plasma concentration-time curve from time zero to infinity $\left(\mathrm{AUC}_{0-\infty}\right), 58.2 \mathrm{ng} \mathrm{h}^{2} / \mathrm{mL}$.

Conclusions Further comparisons of the pharmacokinetic parameters of risperidone and 9-hydroxyrisperidone in plasma of patients administered VAL401 and the corresponding parameters obtained from published data for conventionally formulated risperidone provide evidence for altered biological processing of VAL401 as compared to risperidone. The absolute values obtained provide support for future studies of VAL401 as a cancer treatment, as the $C_{\max }$ demonstrates sufficient exposure to reach the concentrations seen during preclinical anticancer testing, yet the overall exposure to the active moiety supports the use of the safety and tolerability data from conventional risperidone during future clinical trials.
\end{abstract}

Electronic supplementary material The online version of this article (https://doi.org/10.1007/s13318-018-00538-4) contains supplementary material, which is available to authorized users.

Suzanne J. Dilly

suzanne.dilly@valirx.com

1 ValiSeek Limited, 16 Upper Woburn Place, London WC1H 0BS, UK

2 School of Chemistry, University of Leeds, Leeds LS2 9JT, UK

3 Ariana Pharmaceuticals, 43-47 Av de la Grande Armée, 75116 Paris, France

\section{Key Points}

Risperidone has been formulated into a lipid carrier system to be administered orally for use as a treatment for patients with lung cancer

Pharmacokinetic data demonstrate that exposure to risperidone and its active metabolite, 9-hydroxy-risperidone, when using the lipid formulation is comparable to that reported in the literature for the conventional oral formulation, with the exception of a reduced plasma half-life 


\section{Introduction}

Risperidone has a long history of use as an atypical antipsychotic; it appeared on the WHO list of essential medicines in 2013 [1] and is the subject of positive Cochrane reviews supporting its use in schizophrenia [2]. Risperidone use is recognised to be beneficial against various behavioural and psychotic disorders in adults and adolescents [3].

Off-label use in the palliative care of late-stage cancer patients has been reported, with positive benefits including the treatment of opioid-induced nausea [4], allowing pain relief to be increased, and chemotherapy-induced delirium [5]. This use and the popularity of the drug continues despite the black box warning of the FDA against all antipsychotics of this group in relation to their use in elderly patients who potentially have dementia. This warning is due to an increased risk of death, reportedly due to cardiovascular events. Common side effects that are less serious are recognised to be weight gain, fatigue, and gynaecomastia in pre-pubescent males [6].

Several meta-analysis studies have proved contradictory and inconclusive as to whether typical and atypical antipsychotics have any additional direct anticancer or cancerprotective benefits $[7,8]$.

Our preclinical studies showed that a formulation of risperidone with the naturally occurring conjugated linoleic acid known as rumenic acid (9-cis,11-trans-linoleic acid) provides potential anticancer activity, while preclinical testing of unformulated risperidone did not [9]. We postulated that the anticancer activity originates from the inhibition of the intracellular enzyme HSD10 (hydroxysteroid dehydrogenase type 10), and that the formulation facilitated this inhibition in vivo. Although HSD10 has not previously been the subject of oncology drug development, reports of its mechanism of action are emerging in the literature $[10,11]$.

Herein, we start to explore how rumenic acid affects the pharmacokinetic distribution of risperidone in humans in order to establish whether it is reasonable to expect the VAL401 formulation, consisting of an equimolar ratio of risperidone to rumenic acid, to give different therapeutic outcomes as compared to simple risperidone when used in the cancer clinic. To facilitate the delivery of this mixture, VAL401 has been formulated with lipid excipientsa homogeneous liquid of Capryol PGMC, Lauroglycol 90, Capryol 90 and Aerosil 200.

We conducted a phase 2 clinical trial in late-stage nonsmall cell lung cancer patients. The full trial objectives were to assess the safety, tolerability, pharmacokinetics and efficacy of VAL401 in the treatment of patients with locally advanced or metastatic non-small cell lung adenocarcinoma, although only the pharmacokinetic parameters are provided in the present manuscript. By measuring the blood concentrations of both risperidone and its primary metabolite, 9-hydroxyrisperidone, after a single oral dose, the combined effect of the new formulation in the specified population was compared with historic data on the absorption, metabolism and clearance of risperidone.

\section{Methods}

This open-label phase 2 clinical trial was conducted at two clinical sites in Tbilisi, Georgia, and identified by ClinicalTrials.gov identifier NCT02875340 (EudraCT number: 2016-000535-41). All procedures performed in the study were in accordance with the ethical standards of the institutional research committee. The principles of GCP were applied throughout and the study was completed according to the guidelines of the Declaration of Helsinki (1964) and later amendments to it. Local ethics approval was sought at each site for the initial protocol and for protocol amendments. All participants provided written informed consent before commencing any study-related procedures.

\subsection{Study Participants}

Patients were recruited if they had a diagnosis of stage IIIB or IV non-small cell adenocarcinoma of the lung, whereby the disease was classified as measurable by RECIST 1.1 and was relapsed or metastatic after prior chemotherapy. The eligibility criteria required the patients to have an anticipated minimum 3-month life expectancy and to be capable of understanding, consenting to and complying with the protocol.

Exclusion criteria were radiotherapy or surgery within 4 weeks prior to the first dose of VAL401 or chemotherapy regimens with the potential for delayed toxicity within 6 weeks prior. Patients displaying active or unstable brain metastases, active liver disease (including hepatitis B or C but excluding malignancy) or other active bacterial, viral or systemic fungal infections were also excluded from the study, as were patients who had displayed clinically significant cardiac conditions within 3 months prior to the first dose of VAL401.

\subsubsection{Study Treatment}

VAL401 is a formulation of risperidone in a lipid excipient encapsulated in gelatin capsules for oral consumption. Each gelatin capsule contains $1 \mathrm{mg}$ risperidone as the active pharmaceutical ingredient along with an equimolar proportion of rumenic acid in a homogeneous liquid mixture consisting 
of four excipients: Capryol PGMC (Gattefosse, France) and Lauroglycol 90 (Gattefosse France) as lipid-emulsifying agents, Capryol 90 (Gattefosse France) as a lipid-solubilising agent and Aerosil 200 (Gattefosse France) as a thickening and stabilising agent.

On day 1 of treatment, all patients were administered $2 \times 1 \mathrm{mg}$ capsules of VAL401. This dosage was taken at least two hours after eating, and the capsules were swallowed with water.

\subsubsection{Pharmacokinetic Sampling}

After the administration of $2 \mathrm{mg}$ of VAL401 on day 1 of treatment, pharmacokinetic profiles were measured-with $10 \mathrm{ml}$ venous blood collected per sample (Vacuette tubes, EDTA anticoagulant) —at various time points: pre-dose and $10 \mathrm{~min}, 15 \mathrm{~min}, 30 \mathrm{~min}, 1 \mathrm{~h}, 2 \mathrm{~h}, 4 \mathrm{~h}, 8 \mathrm{~h}, 10 \mathrm{~h}$ and $24 \mathrm{~h}$ after dosing.

After thorough mixing to ensure the blood samples were fully exposed to the EDTA anticoagulant in the collection tube, the samples were centrifuged at $2671 \times g$ for $4 \mathrm{~min}$. After centrifugation, the plasma was separated and transferred into two screw-cap aliquot tubes with a minimum of $2 \mathrm{ml}$ of plasma per tube and then stored at -2 to $8^{\circ} \mathrm{C}$, ready for analysis.

\subsubsection{Bioanalytical Methods}

Risperidone and 9-hydroxyrisperidone were measured according to the methods described by Fisher [12] and exemplified by Bowskill [13]. The plasma was extracted into butyl acetate:butanol $(9+1, \mathrm{v} / \mathrm{v})$ and a portion of the extract was analysed by LC-MS/MS $(100 \mathrm{~mm} \times 2.1 \mathrm{~mm}$ i.d. Waters Spherisorb S5SCX; eluent: $50 \mathrm{mmol} / \mathrm{L}$ methanolic ammonium acetate, $\mathrm{pH}$ 6.0; flow rate: $0.5 \mathrm{~mL} / \mathrm{min}$; positive ion APCI-SRM). The results were reported as $\mathrm{ng} / \mathrm{mL}$ risperidone and 9-hydroxyrisperidone. This analytical method provides concentrations between the lower level of quantification of $2 \mathrm{ng} / \mathrm{ml}$ (below which the concentration was considered to be zero) and the upper limit for the assay of $200 \mathrm{ng} / \mathrm{ml}$ (above which none of our samples fell). Analyses of internal quality control solutions containing both analytes at concentrations of $6 \mathrm{ng} / \mathrm{ml}, 15 \mathrm{ng} / \mathrm{ml}$ and $70 \mathrm{ng} / \mathrm{ml}$ were routinely interspersed with patient sample analyses. The accuracy and precision of this method are reported to be within $10 \%$ [12].

\subsubsection{Pharmacokinetic Analysis}

Pharmacokinetic parameters were determined from measurements of the plasma concentrations of risperidone and 9-hydroxyrisperidone at each sampling timepoint using noncompartmental analysis as implemented with the R Core
Team PK package [14, 15]. Briefly, in [15], the authors propose an approach based on Riemann sum and asymptotic estimators that does not require any assumption of a particular model.

Noncompartmental analysis via the PK package tends to overestimate the half-life due to the absorption time, which is not taken into account in the model [15]. The actual half-life is therefore shorter than the estimated reported half-life in this analysis, which can be considered a higher bound.

The "total active moiety"- the simple sum of the measured risperidone and 9-hydroxyrisperidone concentrations-was calculated to allow a comparison with literature values for conventionally formulated risperidone. This approach was applied to mitigate the variability in slow and fast metabolisers of risperidone to 9-hydroxyrisperidone via the cytochrome $\mathrm{P} 450$ mechanism [16]. Hence, the total active moiety was calculated by summing the concentrations of risperidone and 9-hydroxyrisperidone (the "combined" approach) or by summing the values of the extracted parameters when appropriate (the "ParamSum" approach), as Riemann-sum-based calculations are sensitive to the number of sampling timepoints and values below the level of quantification, and several patients had measured concentrations below the level of quantification. By comparing the distributions obtained through the "combined" and "ParamSum" approaches, we assessed whether our method could lead to the incoherent estimation of pharmacokinetic parameters.

\subsubsection{Pharmacokinetic Parameters}

Area under the plasma concentration-time curve from time zero to infinity $\left(\mathrm{AUC}_{0-\text { inf }}\right.$ ), clearance, mean residence time (MRT) and half-life were estimated. The following additional parameters were also extracted: volume of the distribution at steady state $\left(V_{\mathrm{dss}}\right)$, clearance $(\mathrm{Cl})$, area under the first moment curve $\left(\mathrm{AUMC}_{0 \text {-inf }}\right)$ and area under the curve from the time of dosing to the last measurable concentration $\left(\mathrm{AUC}_{0-t}\right)$. The maximum peak concentration $\left(C_{\max }\right)$ and time to maximum concentration $\left(T_{\max }\right)$ were estimated using the maximum measured concentration value.

Considering that the dosage was administered orally, after the pharmacokinetic parameters had been calculated, they were adjusted to reflect an equivalent dose of $1 \mathrm{mg}$ for each patient when determining $C_{\text {max }}, C_{\text {last }}$, AUC and AUMC, as required by the method proposed in [15]. Given that the plasma concentration of risperidone can be considered to be proportional to the dose within the therapeutic range of $1-16 \mathrm{mg}$ daily dosage [17], $C_{\max }, C_{\text {last }}$, AUC and AUMC were dose-normalized to allow a straightforward comparison of our data with previously published data. The median 
values of these previously published pharmacokinetic parameters for risperidone, 9-hydroxyrisperidone, and the total active moiety are reported [18].

The $\mathrm{AUC}_{0-\text { inf }}$ distributions obtained using the "combined" and "ParamSum" approaches were compared using Kolmogorov-Smirnov and Kruskal-Wallis tests. Given the nonsignificant $p$ values obtained (Kolmogorov-Smirnov, $p=0.98$; Kruskal-Wallis, $p=0.43$ ), we concluded that the two distributions were similar: the limited number of sampling timepoints did not lead to significant approximation errors when estimating the pharmacokinetic parameters.

\section{Results}

Eight eligible patients were recruited into the trial and therefore received at least one dose of VAL401 at $2 \mathrm{mg}$. At screening, these patients were observed to have a mean age of 65.8 years (range: $54-76$ years) and a mean weight of $68.3 \mathrm{~kg}$ (range: $56-82 \mathrm{~kg}$ ). There were three female and five male participants. Four of the participants were recorded as being ex-smokers and four had never smoked. All eight participants identified themselves as non-Hispanic whites.

The concentration-time data collected for all eight patients on day 1 of dosing are displayed in graphical format in Fig.
$\mathrm{S} 1$ and in tabular format in Table $\mathrm{S} 1$ of the electronic supplementary material (ESM), with mean data presented in Fig. 1.

The product monograph for the traditional, immediate release, oral formulation of risperidone developed and marketed by Janssen includes pharmacokinetic data, but only for a dosage of $1 \mathrm{mg}$. That study included 42 subjects with different ages and liver health profiles [19]. Since the pharmacokinetics of risperidone are considered proportional to the dose delivered within the therapeutic range of 1-16 mg daily dosage $[17,19]$, it is possible to convert the results obtained with the $2 \mathrm{mg}$ dosage used in our study so that those results can be compared to the literature data for the conventional $1 \mathrm{mg}$ dosage. Demographic information on the subjects from the Janssen study of risperidone and the demographics of the patients administered VAL401 are summarised in Table 1.

Tables 2 and 3 show that risperidone and 9-hydroxyrisperidone have different pharmacokinetic profiles regarding clearance and mean residence time or half-life when administered as the VAL401 formulation: their $C_{\max }$ values are similar but the AUC is greater for 9-hydroxyrisperidone than for risperidone. The results from the "combined" and "ParamSum" approaches are shown in Table 2 and Table S2 of the ESM to allow comparison.

We also compared the pharmacokinetic parameter values obtained in our study with the data in the manufacturer's monograph detailing the pharmacokinetics of risperidone (see
Fig. 1 Mean concentrations in plasma plotted as time courses for risperidone (dotted line), its active metabolite 9-hydroxyrisperidone (dashed line) and the total active moiety (the sum of the concentrations of risperidone and 9-hydroxyrisperidone, solid line). Each error bar represents the standard error of the mean (SEM)

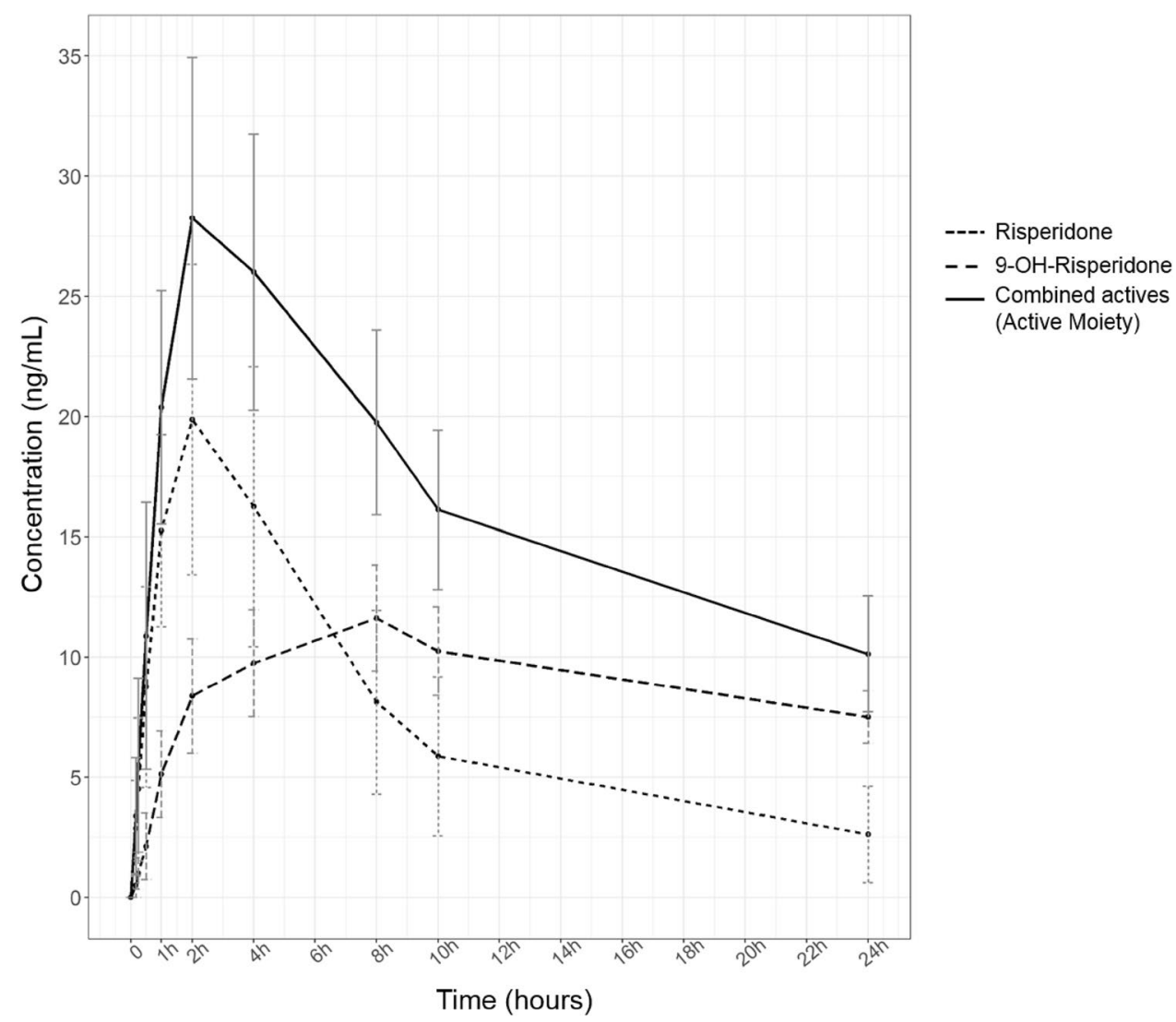


Table 1 Summary of demographic information for the subjects in the Janssen study [18] and the patients in the VAL401 study

\begin{tabular}{|c|c|c|c|c|c|c|c|}
\hline \multirow[t]{2}{*}{ Parameter } & \multicolumn{6}{|c|}{ Subjects in the Janssen study [18] } & \multirow{2}{*}{$\begin{array}{l}\text { Lung-cancer } \\
\text { patients adminis- } \\
\text { tered VAL401 in the } \\
\text { present study }\end{array}$} \\
\hline & $\begin{array}{l}\text { Young } \\
\text { (count and } \\
\text { mean } \pm S D)\end{array}$ & $\begin{array}{l}\text { Elderly } \\
\text { (count and } \\
\text { mean } \pm S D)\end{array}$ & $\begin{array}{l}\text { Liver disease } \\
\text { (count and } \\
\text { mean } \pm \mathrm{SD} \text { ) }\end{array}$ & $\begin{array}{l}\text { Moderate renal } \\
\text { disease (count and } \\
\text { mean } \pm S D)\end{array}$ & $\begin{array}{l}\text { Severe renal } \\
\text { disease (count and } \\
\text { mean } \pm \text { SD) }\end{array}$ & $\begin{array}{l}\text { All } \\
\text { patients } \\
\text { (count } \\
\text { and } \\
\text { mean) }\end{array}$ & \\
\hline No. of subjects & 8 & 12 & 8 & 7 & 7 & 42 & 8 \\
\hline \multicolumn{8}{|l|}{ Gender } \\
\hline Male & 5 & 7 & 3 & 3 & 4 & 22 & 5 \\
\hline Female & 3 & 5 & 5 & 4 & 3 & 20 & 3 \\
\hline Age (years) & $30 \pm 4$ & $69 \pm 4$ & $51 \pm 12$ & $56 \pm 13$ & $52 \pm 13$ & 52 & $65.8 \pm 9$ \\
\hline $\begin{array}{l}\text { Age range } \\
\text { (years) }\end{array}$ & $25-35$ & $65-78$ & $35-73$ & $34-68$ & $29-66$ & $38-64$ & $54-76$ \\
\hline Weight (kg) & $78 \pm 19$ & $78 \pm 16$ & $85 \pm 17$ & $82 \pm 18$ & $78 \pm 20$ & 80 & $68.3 \pm 9$ \\
\hline Height $(\mathrm{cm})$ & $172 \pm 15$ & $169 \pm 10$ & $166 \pm 11$ & $170 \pm 15$ & $174 \pm 9$ & 170 & $169 \pm 7$ \\
\hline
\end{tabular}

Tables 2 and 4). While the values calculated in the present work for the AUC, the $C_{\max }$ and the clearance of risperidone alone and in combination with 9-hydroxyrisperidone are very similar to the manufacturer's data, the half-life values from the present work are shorter, particularly that for the total active moiety. Since the clearance values are similar, this difference cannot be attributed to the elimination process. It may be due to differences in distribution, perhaps influenced by the lipid formulation, the patient's disease state, or both.

\section{Discussion}

The use of lipids such as tri-, di- and monoglycerides and fatty acids in drug formulations dates back at least 50 years, with the principal aim being to improve oral availability [22]. More recently, researchers have introduced bettercharacterised formulations, known as "nanostructured lipid carriers" (NLCs), with the same goal of increasing oral absorption [23], especially with poorly water-soluble class II drugs (which present high permeability but low solubility according to the Biopharmaceutics Classification System). For example, Mandpe et al. [18] reported a substantial increase in the oral bioavailability of iloperidone, which is chemically very similar to risperidone, in Wistar rats when the iloperidone was formulated in a NLC. However, risperidone is known to be well absorbed orally [24-26], so our motivation in this study was not to change the overall bioavailability. Rather, research into iloperidone suggests that the presence of the lipid alters its absorption characteristics and thus, potentially, the pharmacokinetic distribution of iloperidone after intestinal absorption.

In this context, we note a recent series of papers on the pharmacokinetic fate, in mice, of the breast cancer treatment tamoxifen, another class II drug, when formulated in a NLC
[27]. VAL401 is not a NLC, and tamoxifen is chemically different to risperidone. Nevertheless, that study of the pharmacokinetic fate of a poorly soluble drug formulated with a lipid offers valuable insights. The researchers concluded that the presence of the lipid led to increased uptake of the drug via the intestinal lymphatic system, thus bypassing the "first pass" metabolism of the drug by cytochrome $\mathrm{P} 450$ enzymes in the liver. Consistent with their hypothesis, the half-life of tamoxifen in the mice was significantly longer than observed for a standard suspension of the drug.

Pharmacokinetic effects are predicted to be more complex with lipid-formulated risperidone. The active moiety that provides the therapeutic benefit of risperidone is well known to be a combination of the drug itself and the metabolite 9-hydroxyrisperidone, which arises from the action of cytochrome P450 enzymes, primarily in the liver [28]. Thus, in the case of risperidone, bypassing the liver could change the ratio of risperidone to 9-hydroxyrisperidone, potentially affecting the pharmacokinetics and therapeutic outcomes.

To explore this hypothesis further, we present Table 3, showing a comparison of 9-hydroxyrisperidone to risperidone pharmacokinetic parameter ratios. This again shows that when the overall populations of both studies are compared, the half-life shows the greatest difference, but also that the data obtained in our study align most closely with the data obtained for the elderly subsection of patients reported by Janssen. These data suggest that the ratio of the AUC for 9-hydroxyrisperidone to the AUC for risperidone in our patients is the same as the corresponding ratio obtained when the risperidone was administered conventionally. Lymphatic uptake, if there was any, did not affect this ratio. On the other hand, the relatively slow appearance of both drug components in the blood in the present study as compared with Janssen's study (Table 2) is consistent with 
Table 2 Summary of the median values of pharmacokinetic parameters for risperidone, 9-hydroxyrisperidone and the combination of these two active molecules (as calculated using the "combined" approach) from the Janssen study [18] and the present study of patients administered VAL401

\begin{tabular}{|c|c|c|c|c|c|c|c|c|}
\hline \multirow[t]{2}{*}{ Parameter } & \multirow[t]{2}{*}{ Units } & \multicolumn{6}{|c|}{ Subjects in the Janssen study [18] } & \multirow{2}{*}{$\begin{array}{l}\text { Lung-cancer patients } \\
\text { administered } \\
\text { VAL401 in the pre- } \\
\text { sent study (median) }\end{array}$} \\
\hline & & Young (median) & $\begin{array}{l}\text { Elderly } \\
\text { (median) }\end{array}$ & $\begin{array}{l}\text { Liver } \\
\text { disease } \\
\text { (median) }\end{array}$ & $\begin{array}{l}\text { Moderate } \\
\text { renal disease } \\
\text { (median) }\end{array}$ & $\begin{array}{l}\text { Severe renal } \\
\text { disease } \\
\text { (median) }\end{array}$ & $\begin{array}{l}\text { All patients } \\
(\text { mean }+ \text { SD })\end{array}$ & \\
\hline \multicolumn{9}{|l|}{ Risperidone } \\
\hline$T_{\max }$ & $\mathrm{h}$ & 1 & 1 & 1 & 1 & 1 & $1 \pm 0$ & 2 \\
\hline$C_{\max }$ & $\mathrm{ng} / \mathrm{ml}$ & 5.33 & 6.37 & 8.16 & 9.6 & 9.65 & $7.8 \pm 1.9$ & $8^{*}$ \\
\hline$C_{\text {last }}$ & $\mathrm{ng} / \mathrm{ml}$ & - & - & - & - & - & - & $1.5^{*}$ \\
\hline$t_{1 / 2}$ & $\mathrm{~h}$ & 2.9 & 3.3 & 8.16 & 9.6 & 9.65 & $6.7 \pm 3.4$ & 3.5 \\
\hline$V_{\mathrm{dss}}$ & $\mathrm{mL}$ & - & - & - & - & - & - & 113.9 \\
\hline $\mathrm{AUC}_{0-\infty}$ & $\mathrm{ng} \cdot \mathrm{h} / \mathrm{mL}$ & 23.5 & 26.2 & 35.9 & 65.8 & 48.6 & $40 \pm 17.5$ & $58.2 *$ \\
\hline $\mathrm{AUC}_{0 \text {-last }}$ & $\mathrm{ng} \cdot \mathrm{h} / \mathrm{mL}$ & - & - & - & - & - & - & $49.8^{*}$ \\
\hline $\mathrm{AUMC}_{0-\infty}$ & $\mathrm{ng} \cdot \mathrm{h}^{2} / \mathrm{mL}$ & - & - & - & - & - & - & $237.9^{*}$ \\
\hline $\mathrm{Cl}_{\text {oral }}$ & $\mathrm{mL} / \mathrm{min}$ & 714 & 642 & 465 & 253 & 343 & $483.4 \pm 194.6$ & 286.4 \\
\hline MRT & $\mathrm{h}$ & - & - & - & - & - & - & 5.1 \\
\hline \multicolumn{9}{|c|}{ 9-Hydroxyrisperidone } \\
\hline$T_{\max }$ & $\mathrm{h}$ & 3 & 2 & 6.5 & 5 & 5 & $4.3 \pm 1.8$ & 8 \\
\hline$C_{\max }$ & $\mathrm{ng} / \mathrm{ml}$ & 4.26 & 5,01 & 2.36 & 5.21 & 5.63 & $4.5 \pm 1.3$ & $5.8^{*}$ \\
\hline$C_{\text {last }}$ & $\mathrm{ng} / \mathrm{ml}$ & - & - & - & - & - & - & $1.8^{*}$ \\
\hline$t_{1 / 2}$ & $\mathrm{~h}$ & 16.5 & 23.4 & 17.9 & 27.2 & 33.6 & $23.7 \pm 7$ & 23.4 \\
\hline$V_{\mathrm{dss}}$ & $\mathrm{mL}$ & - & - & - & - & - & - & 181 \\
\hline $\mathrm{AUC}_{0-\infty}$ & $\mathrm{ng} \cdot \mathrm{h} / \mathrm{mL}$ & 98.7 & 150 & 88.2 & 220 & 257 & $162.8 \pm 74.1$ & $276.3^{*}$ \\
\hline $\mathrm{AUC}_{0-\text { last }}$ & $\mathrm{ng} \cdot \mathrm{h} / \mathrm{mL}$ & - & - & - & - & - & - & $108.1^{*}$ \\
\hline $\mathrm{AUMC}_{0-\infty}$ & $\mathrm{ng} \cdot \mathrm{h}^{2} / \mathrm{mL}$ & - & - & - & - & - & - & $9295.8^{*}$ \\
\hline $\mathrm{Cl}_{\text {oral }}$ & $\mathrm{mL} / \mathrm{min}$ & - & - & - & - & - & - & 60.5 \\
\hline MRT & $\mathrm{h}$ & - & - & - & - & - & - & 33.8 \\
\hline \multicolumn{9}{|c|}{ Total active moiety (risperidone +9 -hydroxyrisperidone) calculated using the "combined" approach } \\
\hline$T_{\max }$ & $\mathrm{h}$ & 2 & 1.5 & 1 & 1 & 2 & $1.5 \pm 0.8$ & 3 \\
\hline$C_{\max }$ & $\mathrm{ng} / \mathrm{ml}$ & 9.1 & 10.2 & 8.5 & 13 & 13.3 & $13 \pm 5.8$ & $11.3^{*}$ \\
\hline$C_{\text {last }}$ & $\mathrm{ng} / \mathrm{ml}$ & - & - & - & - & - & - & $7.3^{*}$ \\
\hline$t_{1 / 2}$ & $\mathrm{~h}$ & 17 & 23 & 16 & 25 & 29 & $22 \pm 5.5$ & 9 \\
\hline$V_{\mathrm{dss}}$ & $\mathrm{mL}$ & - & - & - & - & - & - & 73.3 \\
\hline $\mathrm{AUC}_{0-\infty}$ & $\mathrm{ng} \cdot \mathrm{h} / \mathrm{mL}$ & 132 & 189 & 145 & 272 & 417 & $231 \pm 117.5$ & $216.6^{*}$ \\
\hline $\mathrm{AUC}_{0 \text {-last }}$ & $\mathrm{ng} \cdot \mathrm{h} / \mathrm{mL}$ & - & - & - & - & - & - & $88.3^{*}$ \\
\hline $\mathrm{AUMC}_{0-\infty}$ & $\mathrm{ng} \cdot \mathrm{h}^{2} / \mathrm{mL}$ & - & - & - & - & - & - & $4737.2 *$ \\
\hline $\mathrm{Cl}_{\text {oral }}$ & $\mathrm{mL} / \mathrm{min}$ & 127 & 89 & 119 & 61 & 40 & $87.2 \pm 37.1$ & 76.9 \\
\hline MRT & $\mathrm{h}$ & - & - & - & - & - & - & 13 \\
\hline
\end{tabular}

Subjects in the Janssen study [18] were administered $1 \mathrm{mg}$ risperidone, whereas the patients in the present study were administered $2 \mathrm{mg}$ VAL401. Dose-normalised (to $1 \mathrm{mg}$ of risperidone) VAL401 pharmacokinetic parameter values are reported for $C_{\max }, \mathrm{AUC}_{0-\infty}, \mathrm{AUC}_{0-\mathrm{last}}$ and $\mathrm{AUMC}_{0-\infty}$, as indicated by an asterisk

Data on the metabolite (9-hydroxyrisperidone) oral clearance $\left(\mathrm{Cl}_{\text {oral }}\right)$ and volume of distribution at steady state $\left(V_{\mathrm{dss}}\right)$ were not available for the Janssen study subjects

- Data unavailable

a delayed appearance in the blood due to lymphatic uptake. Direct measurements of drug levels in the lymph would be needed to fully answer this question.

The requirement of this formulation for potential anticancer activity goes some way to explaining the lack of clarity from previous meta-analyses, which did not control for dietary factors in order to accommodate the formulation requirement. With rumenic acid being plentiful in dairy and beef products [29], it could be expected that the subjects included in the meta-analysis would only display a positive impact of risperidone against cancer if it was routinely taken with, for example, a glass of milk. 
Table 3 Metabolite-to-parent (i.e. 9-hydroxyrisperidone to risperidone) pharmacokinetic parameter ratios for each patient group in the Janssen study [18] and for the patients administered VAL401 in the present study

\begin{tabular}{|c|c|c|c|c|c|c|c|}
\hline \multirow[t]{2}{*}{ Parameter } & \multicolumn{6}{|c|}{ Subjects in the Janssen study [18] } & \multirow{2}{*}{$\begin{array}{l}\text { Lung-cancer patients } \\
\text { administered VAL401 } \\
\text { in the present study }\end{array}$} \\
\hline & Young & Elderly & Liver disease & $\begin{array}{l}\text { Moderate renal } \\
\text { disease }\end{array}$ & $\begin{array}{l}\text { Severe renal } \\
\text { disease }\end{array}$ & All patients & \\
\hline \multicolumn{8}{|c|}{ 9-Hydroxyrisperidone/risperidone pharmacokinetic parameter ratios } \\
\hline$T_{\max }$ & 3.0 & 2.0 & 6.5 & 5.0 & 5.0 & 4.3 & 5.8 \\
\hline$C_{\max }$ & 0.8 & 0.8 & 0.3 & 0.5 & 0.6 & 0.6 & 0.7 \\
\hline$C_{\text {last }}$ & - & - & - & - & - & - & 1.2 \\
\hline$t_{1 / 2}$ & 5.7 & 7.1 & 2.2 & 2.8 & 3.5 & 3.5 & 6.7 \\
\hline$V_{\mathrm{dss}}$ & - & - & - & - & - & - & 1.6 \\
\hline $\mathrm{AUC}_{0-\infty}$ & 4.2 & 5.7 & 2.5 & 3.3 & 5.3 & 4.1 & 4.7 \\
\hline $\mathrm{AUC}_{0-\text { last }}$ & - & - & - & - & - & - & 2.2 \\
\hline $\mathrm{AUMC}_{0-\infty}$ & - & - & - & - & - & - & 39.1 \\
\hline $\mathrm{Cl}_{\text {oral }}$ & - & - & - & - & - & - & 0.2 \\
\hline MRT & - & - & - & - & - & - & 6.6 \\
\hline
\end{tabular}

- Data unavailable

Consideration of the off-label use in addition to the recognised side effects of risperidone provides support for

Table 4 Summary of differences in median pharmacokinetic parameter values between VAL401 patients and elderly Janssen study subjects $\left(\mathrm{J}_{\text {Elderly }}\right)$, and between VAL401 patients and all Janssen study subjects $\left(\mathrm{J}_{\mathrm{All}}\right)$ for risperidone, 9-hydroxyrisperidone and the combination of them (i.e. the active moiety, as calculated using the "combined" approach)

\begin{tabular}{|c|c|c|c|}
\hline Parameter & Units & VAL401 - $\mathrm{J}_{\text {Elderly }}$ & VAL401 $-\mathrm{J}_{\text {All }}$ \\
\hline
\end{tabular}

\section{Risperidone}

$C_{\max }$

$$
\mathrm{h}
$$

$t_{1 / 2}$

$\mathrm{ng} / \mathrm{ml}$

1

1

$$
\mathrm{h}
$$

$2 *$

$0.2^{*}$

$\mathrm{AUC}_{0-\infty} \quad \mathrm{ng} \cdot \mathrm{h} / \mathrm{mL}$

$$
0.2
$$

$-3.2$

$\mathrm{Cl}_{\text {oral }}$

$\mathrm{mL} / \mathrm{min}$

$-355.6$

$18 *$

$-197$

9-Hydroxyrisperidone

$\begin{array}{llll}T_{\max } & \mathrm{h} & 3.7 & 3.7 \\ C_{\text {max }} & \mathrm{ng} / \mathrm{ml} & 0.8^{*} & 1.3^{*} \\ t_{1 / 2} & \mathrm{~h} & 0 & -0,3 \\ \mathrm{AUC}_{0-\infty} & \mathrm{ng} \cdot \mathrm{h} / \mathrm{mL} & 126^{*} & 113.5^{*} \\ \mathrm{Cl}_{\text {oral }} & \mathrm{mL} / \mathrm{min} & - & -\end{array}$

Total active moiety (risperidone +9 -hydroxyrisperidone) calculated using the "combined" approach

\begin{tabular}{llll}
$T_{\max }$ & $\mathrm{h}$ & 1.5 & 1.5 \\
$C_{\max }$ & $\mathrm{ng} / \mathrm{ml}$ & $1^{*}$ & $-2^{*}$ \\
$t_{1 / 2}$ & $\mathrm{~h}$ & -14 & -13 \\
$\mathrm{AUC}_{0-\infty}$ & $\mathrm{ng} \cdot \mathrm{h} / \mathrm{mL}$ & $28^{*}$ & $-14^{*}$ \\
$\mathrm{Cl}_{\text {oral }}$ & $\mathrm{mL} / \mathrm{min}$ & -12.1 & -10.3 \\
\hline
\end{tabular}

Where applicable, the differences in parameter values are dose-normalised (to $1 \mathrm{mg}$ dosage) for the VAL401 cohort, as indicated by an asterisk

- Data unavailable its use in cancer patients, with the primary side effect of weight gain representing a benefit to patients suffering from cachexia [30], fatigue being a common and socially acceptable side effect of oncology, and pre-pubescent males being readily excluded from the patient population.

However, the patient population of cancer sufferers is predominantly composed of elderly patients with a tendency to present dementia and potentially multiorgan dysfunction during end-stage disease, so it is important to first establish the safety and pharmacokinetic profile of the risperidone in the new lipid formulation. Variation in the pharmacokinetic profile from that of the conventionally formulated risperidone was expected when administering VAL401, due to the presentation of the pharmaceutical ingredient in a lipid (as detailed above) and the suboptimal medical condition of the patient population.

Snoeck et al. observed that the pharmacokinetics of risperidone, 9-hydroxyrisperidone and the total active moiety varied with the population considered (young, elderly, liver disease or renal disease patients), with liver disease patients showing the lowest metabolism of risperidone to 9-hydroxyrisperidone and age making very little difference. The age ranges considered in the present work support our intention to use the reported data on an elderly population for comparison, while noting that comorbidities will be many and varied in the late-stage cancer patients for whom VAL401 is mainly intended [31].

Upon inspecting the data displayed in Table 2, it is clear that the AUC, $C_{\max }$ and clearance values are comparable to those expected [20], but also that there is a decrease in the half-life of the total active moiety when using the lipid formation. With the caveats that our study population was small and highly comorbid, this singular difference in the 
observed pharmacokinetics supports the hypothesis that the active risperidone and 9-hydroxyrisperidone components remain associated with the lipid excipients of the formulation after intestinal absorption.

The observed reduction in the half-life at approximately constant $C_{\max }$ means that the volume of distribution $V_{\mathrm{dss}}$ is lower with VAL401 than with standard risperidone. $V_{\mathrm{dss}}$ is known to be affected by (among other factors) the degree to which the drug binds to proteins in the plasma. If more of the drug binds to plasma proteins, $V_{\mathrm{dss}}$ will be lower.

A further comparison of the parameter values in Table 2 reveals that although the active moiety displays largely similar pharmacokinetic values to the conventionally formulated risperidone, $T_{\max }$ for 9-hydroxyrisperidone was $8 \mathrm{~h}$ after VAL401 treatment but ranged from $2 \mathrm{~h}$ for elderly patients up to $6.5 \mathrm{~h}$ for liver-disease patients in the Janssen study. The later peak in the concentration of the main metabolite in our study supports the hypothesis of a delay in hepatic metabolism.

Interestingly, the plasma protein binding levels for risperidone and 9-hydroxyrisperidone are rather different: approximately $89 \%$ and $74 \%$, respectively [21]. Hence, a possible explanation for the difference in the pharmacokinetic profiles of VAL401 and conventionally formulated risperidone is that more of the active moiety is present as risperidone rather than 9-hydroxyrisperidone, leading to increased binding of the active moiety by plasma proteins when using VAL401. This would be consistent with the likely increase in lymphatic uptake and decreased "first pass" hepatic metabolism.

As risperidone is a weakly basic drug, it would be expected to bind predominantly to $\alpha$-1-acid glycoprotein (AAG) rather than albumin in the blood [32]. The AAG plasma concentration is seen as a prognostic tool for many cancers, including non-small cell lung cancer, with higher AAG concentrations correlating to poorer outcomes [33]. Hence, it may be expected that the plasma protein binding of risperidone would be greater in end-stage cancer patients than in noncancerous psychotic patients, which could explain the differences we observed. Note also that we are not aware of any research addressing the effect of lipids on plasma protein binding, which could be a further consideration when attempting to explain these differences.

\section{Conclusions}

This study provided a first assessment of the pharmacokinetics of this new lipid formulation of risperidone after a single dose in this specialised end-stage cancer patient population. The exposure of the patients to the active moiety was generally no greater with VAL401 than with the conventionally formulated risperidone, supporting the use of the safety and tolerability data for conventionally formulated risperidone during further testing of VAL401 in the treatment of cancer.

Subsequent studies to explore the pharmacokinetics after multiple and differing doses of VAL401 would provide further information, although it should be noted that both the parent risperidone and metabolite 9-hydroxyrisperidone should be analysed throughout. Further analyses were not possible during this study due to the ethical limitations of performing multiple blood draws from end-stage cancer patients.

The absolute $C_{\max }$ value for the active moiety supports our supposition that $2 \mathrm{mg}$ daily dosage would be sufficient to assess the potential anticancer activity of VAL401, as this would allow the desired level of $20 \mathrm{ng} / \mathrm{mL}$ (as tested in the previously reported in vitro model system [9]) to be attained.

Finally, although this study was developed with the intention to repurpose risperidone for use as a treatment for adenocarcinoma, these pharmacokinetic data on a previously unexplored formulation may also be considered in the context of the treatment of psychosis.

Acknowledgements At ValiSeek we gratefully acknowledge the participation of all patient volunteers in our studies. Those volunteers were recruited at LTD Medulla Chemotherapy and Immunotherapy Clinic, 6 Politkovskaya Street, Tbilisi 0186, Georgia and the Research Institute of Clinical Medicine, 13 Tevdore Mgvdeli Street, Tbilisi 0112, Georgia. We also wish to recognise and thank our collaborators at Clinical Accelerator Limited for their continued project management and support throughout this study. Pharmacokinetic analysis was carried out by Viapath LLP (London); we thank Simon Handley for his dedication in providing prompt data and detailed explanations.

\section{Compliance with Ethical Standards}

Funding This study was funded by ValiSeek Limited, a subsidiary of Valirx plc, London, UK.

Conflict of Interest SJD is employed by and is a shareholder and director of ValiSeek Limited, and is also a shareholder and director of Tangent Reprofiling Limited. PCT is a shareholder and director of Tangent Reprofiling Limited. GSM is employed by and is a director and shareholder of Valirx plc, and is a director of ValiSeek. MA is employed by and is a shareholder of Ariana Pharmaceuticals, Paris, France. FP and CW are employed by Ariana Pharmaceuticals, Paris, France.

Ethics Approval All procedures performed in studies involving human participants were in accordance with the ethical standards of the institutional research committee. The principles of GCP were applied throughout and the study was completed according to the guidelines of the Declaration of Helsinki (1964) and later amendments. Local ethics approval was sought at each site for the initial protocol and for protocol amendments.

Informed Consent Informed consent forms were signed and dated by all patients and investigators prior to enrolment in the study. All patients were made aware of their rights and their ability to withdraw consent to any procedures at any time and without prejudice. 
Open Access This article is distributed under the terms of the Creative Commons Attribution-NonCommercial 4.0 International License (http://creativecommons.org/licenses/by-nc/4.0/), which permits any noncommercial use, distribution, and reproduction in any medium, provided you give appropriate credit to the original author(s) and the source, provide a link to the Creative Commons license, and indicate if changes were made.

\section{References}

1. World Health Organization. The selection and use of essential medicines: report of the WHO Expert Committee, 2013 (including the 18th WHO Model List of Essential Medicines and the 4th WHO Model List of Essential Medicines for Children). Geneva: World Health Organization; 2014. pp. 80-81.

2. Rattehalli RD, Zhao S, Li BG, Jayaram MB, Xia J, Sampson S. Risperidone versus placebo for schizophrenia. Cochrane Database Syst Rev. 2016;12:CD006918.

3. Vitiello B, Correll C, Zwieten-Boot B, Zuddas A, Parellada M, Arango C. Antipsychotics in children and adolescents: increasing use, evidence for efficacy and safety concerns. Eur J Psychopharmacol. 2009;19(9):629-35.

4. Okamoto $\mathrm{Y}$, Tsuneto $\mathrm{S}$, Matsuda $\mathrm{Y}$, Inoue $\mathrm{T}$, Tanimukai $\mathrm{H}$, Tazumi K, Ono Y, Kurokawa N, Uejima EA. Retrospective chart review of the antiemetic effectiveness of risperidone in refractory opioid-induced nausea and vomiting in advanced cancer patients. J Pain Symptom Manag. 2007;34(2):217-22.

5. Breitbart W, Alici Y. Evidence based treatment of delirium in patients with cancer. J Clin Oncol. 2012;30:1206-14.

6. Piparva KG, Buch JG, Chandrani KV. Analysis of adverse drug reactions of atypical antipsychotics in psychiatry OPD. Indian J Pyschol Med. 2001;33(2):153-7.

7. Fond G, MacGregor A, Attal J, Larue A, Brittner M, Ducasse D, Capdevielle D. Antipsychotic drugs: pro-cancer or anti-cancer? A systematic review. Med Hypotheses. 2012;79(1):38-42.

8. Hippisley-Cox J, Vinogradova Y, Coupland C, Parker C. Risk of malignancy in patients with schizophrenia or bipolar disorder. Arch Gen Psychiatry. 2007;64(12):1368-76.

9. Dilly SJ, Clark AJ, Marsh A, Mitchell DA, Fishwick CWG, Taylor PC, Cain R. A chemical genomics approach to drug reprofiling in oncology: antipsychotic drug risperidone as a potential adenocarcinoma treatment. Cancer Lett. 2017;393:16-21.

10. Carlson E, Marquez R, Du F, Wang Y, Xu L, Yan S. Overexpression of 17beta-hydroxysteroid dehydrogenase type 10 increase pheocytoma cell growth and resistance to cell death. BMC Cancer. 2015;15:166-80.

11. Rauschenberger $\mathrm{K}$, et al. A non-enzymatic function of $17 \beta$-hydroxysteroid dehydrogenase type 10 is required for mitochondrial integrity and cell survival. EMBO Mol Med. 2009;2:51-62.

12. Fisher DS, Partridge SJ, Handley SA, Couchman L, Morgan PE, Flanagan RJ. LC-MS/MS of some atypical antipsychotics in human plasma, serum, oral fluid and haemolysed whole blood. Forensic Sci Int. 2013;229(1):145-50.

13. Bowskill SVJ, Handley SA, Fisher DS, Flanagan RJ, Patel MX. Risperidone and total 9-hydroxyrisperidone in relation to prescribed dose and other factors: data from a therapeutic drug monitoring service, 2002-2010. Ther Drug Monit. 2012;34:349-55.

14. R Core Team. R: a language and environment for statistical computing. Vienna: R Foundation for Statistical Computing; 2017. www.R-project.org. Accessed 28 Jun 2018.

15. Jaki T, Wolfsegger MJ. Estimation of pharmacokinetic parameters with the R package PK. Pharm Stat. 2011;10(3):294. https://doi. org/10.1002/pst.449.
16. Calarge CA, Miller DD. Predictors of risperidone and 9-hydroxyrisperidone serum concentration in children and adolescents. J Child Adolesc Psychopharmacol. 2011;21(2):163-9.

17. Medicines and Healthcare Products Regulatory Agency (MHRA). UK Public Assessment Report PL 17907/0210-5. London: MHRA. p 31. http://www.mhra.gov.uk/home/groups/par/docum ents/websiteresources/con143699.pdf. Accessed 25 Oct 2018.

18. Mandpe L, Kyadarkunte A, Pokharkar V. Assessment of novel iloperidone- and idebenone-loaded nanostructured lipid carriers: brain targeting efficiency and neuroprotective potential. Ther Deliv. 2013;4(11):1365-83.

19. FDA. Section 12.3. In: Highlights of prescribing information for Risperdal (risperidone). Silver Spring: FDA. https://www.acces sdata.fda.gov/drugsatfda_docs/label/2009/020272s056,02058 8s044,021346s033,021444s03lbl.pdf Accessed 28 Jun 2018.

20. Dammerman R, Kim S, Adera M, Schwarz A. A phase 1, openlabel, single dose pharmacokinetic study in stabilized patients with schizophrenia following risperidone implant. In: Poster session presented at American Psychiatric Association Annual Meeting; 2017 May 20-24; San Diego, CA, USA.

21. Alamo C, Lopez-Munoz F. The pharmacological role and clinical applications of antipsychotics' active metabolites: paliperidone versus risperidone. Clin Exp Pharmacol. 2013;3:1-12.

22. Feeney OM, Crum MF, McEvoy CL, Trevaskis NL, Williams HD, Pouton CW, Charman WN, Bergstrom CA, Porter CJ. 50 years of oral lipid-based formulations: provenance, progress and future perspectives. Adv Drug Deliv Rev. 2016;101:167-94.

23. Beloqui A, Pozo-Rodríguez A, Isla A, Rodríguez-Gascón A, Solinís MA. Nanostructured lipid carriers as oral delivery systems for poorly soluble drugs. J Drug Deliv Sci Technol. 2017;42:144-54.

24. Huang ML, Van Peer A, Woestenborghs R, De Coster R, Heykants J, Jansen AA, Zylicz Z, Visscher HW, Jonkman JH. Pharmacokinetics of the novel antipsychotic agent risperidone and the prolactin response in healthy subjects. Clin Pharmacol Ther. 1993;54(3):257-68.

25. Mannens G, Huang ML, Meuldermans W, Hendrickx J, Woestenborghs R, Heykants J. Absorption, metabolism, and excretion of risperidone in humans. Drug Metab Dispos. 1993;21(6):1134-41.

26. Byerly MJ, DeVane CL. Pharmacokinetics of clozapine and risperidone: a review of recent literature. J Clin Psychopharmacol. 1996;16(2):177-87.

27. Shete HK, Selkar N, Vanage GR, Patravale VB. Tamoxifen nanostructured lipid carriers: enhanced in vivo antitumor efficacy with reduced adverse drug effects. Int J Pharm. 2014;468:1-14.

28. Lynch T, Price A. The effect of cytochrome P450 metabolism on drug response, interactions, and adverse effects. Am Fam Physician. 2007;76(3):391-6.

29. Lawson RE, Moss AR, Givens DI. The role of dairy products in supplying conjugated linoleic acid to man's diet: a review. Nutr Res Rev. 2001;14:153-72.

30. Kracke EJ, Tosh AK. Treatment of anorexia nervosa with long term risperidone in an outpatient setting. SpringerPlus. 2014;3:706-9.

31. Snoeck E, Van Peer A, Sack M, Horton M, Mannens G, Woestenborghs R, Meibach R, Heykants J. Influence of age, renal and liver impairment on the pharmacokinetics of risperidone in man. Psychopharmacology (Berl). 1995;122(3):223-9.

32. Routledge PA. The plasma protein binding of basic drugs. Br J Clin Pharmacol. 1986;22:499-506.

33. Sasaki Y, Kato K, Furuta K, Takahashi N, Shoji H, Honma Y, Iwasa S, Okita NT, Takashima A, Hamaguchi T, Yamada Y, Boku $\mathrm{N}$. Evaluation of $\alpha-1$-acid glycoprotein as a prognostic factor of survival in patients with stage II-III esophageal carcinoma treated with neoadjuvant docetaxel, cisplatin, and fluorouracil chemotherapy followed by surgery. J Clin Oncol. 2015;33(3):100. 